\title{
DE WAALSCHE KERK VAN OOSTBURG . .
}

DOOR

Dr. J. DE HULIU.

Op den 17 October $1685 \mathrm{kwam}$ in de vergadering der Staten-Generaal een request ter tafel, waarin de magistraat van Oostburg berichtte, dat zich een groot getal rófugiess metterwoon „binnen en onder de gemeente van Oostburg" hadden gevestigd. Het waren lieden, schreef hij, die "gaarne tot het gehoor van Gods Woord zouden komen" doch, geen andere taal verstaande dan het Fransch, zich genoodzaakt vonden om, wanneer zij de openbare godsdienstoefeningen wilden bijwonen, naar Groede te gaan, de eenige plaats op het platteland die een kerk bezat waar in het Fransch werd gepredikt. Vermits echter de Groedsche Walenkerk zeer klein was en niet eens, het vierde part der vluchtolingen ontrangen kon" en bovendien Groede en Oostburg "omtrent twee uren" verwijderd lagen, verzocht de magistraat machtiging om, op zoodanig tractement als hun HoogMogenden goed zouden vinden, ten zijnent een Fransche

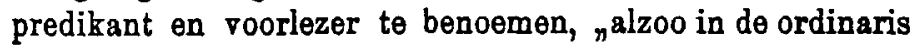
kerk binnen Oostburg op bijzondere uren in het Fransch zou kunnen worden gepredikt" ').

1) Bulletin, I, p. 272.

$\mathbf{X}$. 
De Staten-Generaal toonden zich aanstonds bereid om aan dien wensch te roldoen. Reeds den 19 October namen zij een besluit, waarbij de Waalsche predikant van Sas van Gent, André Corróge, "vermits de kleine Fransche gemeente aldaar" tot wederopzeggens toe naar Oostburg werd verplaatst om er den dienst in het Fransch waar te nemen. De Raad van State, wien de uitroering van dit besluit werd opgedragen, verordende daarop, dat Correge met den Waalschen voorlezer van het Sas zich "met den eersten zouden hebben te transporteeren naar Oostburg" en bepaalde tevens, dat de vereischte actes van tractement voor ben beiden zouden worden afgegeven 1 ).

Nauwelijks had men te Sas van Gent van deze beschikking kennis bekomen of de magistraat on de Waalsche Kerkeraad van het stadje, waarschijnlijk beducht dat hetgeen slechts als een tijdelijke maatregel bedoeld was naderhand in een blijvenden zou veranderd worden en dat dus het voortbestaan van hun Fransche kerk gevaar liep, kwamen

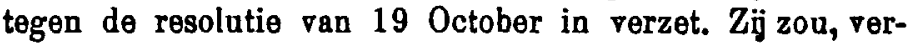
toonden zij in een request aan de Staten-Generaal, groot nadeel toebrengen niet enkel aan de Waalsche gemeente van het Sas zelve, die al over de dertig jaren bestond, maar niet minder aan de Gereformeerden binnen Gent, Wetteren, Oudenaarde, Doornik, Kortrijk, Rijsel en andere plaatsen, die onder den druk van Rome leefden en reeltijds in de Waalsche kerk ran Sas van Gent het Arondmaal en de predikatiën kwamen bijwonen, dank zij de goede gelegenbeid die zij hadden om tot Gent te komen en vandaar per vaartuig in drie uur tijds Sas te bereiken, terwïl daarentegen de afstand van Gent naar Oostburg te voet meer dan negen mijlen bedroeg. Ook waren er, zoo merkten zij op, bereids Waalsche kerken te Sluis, Aardenburg ?)

1) Resolutie Raad van State 5 November 1685.

2) De bewering dat er te Sluis en Aardenburg op dit tijdstip Waalsche kerken bestonden was niet geheel juist. Alleen was in beide plaatsen een van de Nederduitsche predikanten ambtshalve verplicht op gezelte tijden ook een Fransche predikatie te doen; zie Dresselhuis, Waalsche gemeenten in Zeeland, Bergen op Zoom 1848, blz. 21, 23, 67. 
en Groede, alle dicht bij elkander gelegen en te nauwernood twee uur van Oostburg rerwijderd. Zij verzochten daarom, dat de Staten-Generaal hun besluit zouden intrekken, opdat zij Corrége roor hun gemeente behouden mochten ${ }^{1}$ ). Doch de regeering in den Haag liet zich niet verbidden, kort en goed werd aan de Sassenaren tot bescheid gegeren, dat men bij de resolutie van 19 October "bleef persisteeren" en dat mitsdien ,in het voorschreven verzoek niet kon worden getreden" 2).

Op een nader request van de regeering en den kerkeraad van Oostburg, waarin deze machtiging vroegen om Correge, die te Sas van Gent "nooit eenig beroep had gehad of aldaar berestigd was geweest en zulks uit dien hoofde van daar niet kon worden rerplaatst", als Waalsch predikant in hun midden te "beroepen en berestigen naar stijle" 3), werd den 14 November gunstig door de Staten-Generaal beschikt, en spoedig daarna zal nu denkelïk Corrége bij de Oostburgsche vluchtelingen zijn dienst hebben aanvaard.

Lang heeft hij dien echter niet waargenomen, want wat die van Sas van Gent zelf in den Haag niet hadden kunnen erlangen, verwierven zij in den loop der volgende maand door de tusschenkomst van anderen. Uit naam toch van de Waalsche Synode richtte de Waalsche kerkeraad van 's-Gravenhage op het laatst ran Norember een verzoekschrift aan den Raad ran State, om dien onder het oog te brengen, dat het denkbeeld, $n$ door het aanhouden van die van Oostburg" ongetwijfeld bij den Raad opgewekt, $n$ alsof op Sas van Gent het plegen van den godsdienst in de Fransche taal zoo zeer niet meer werd gerequireerd", allen grond miste. Integendeel moesten de requestranten er op wïzen, hoe uiterst noodig het was ndat de kerk op het Sas van Gent werd geconserveerd, alzoo dezelive niet was opgericht met die intentie om de ledematen van die plaats alleen te dienen maar wel inzonderheid om den geloofs-

1) Bulletin, I, p. 273.

2) Resolutie Staten-Generaal 8 November 1685.

1) D.i. in overeenstemming met de kerkelijke verordeningen. 
genooten, die onder het kruis in de naburige steden leefden, mede te strekken tot roedsel van hunne zielen, gelïk dan in het uitdeelen van het Heilig Arondmaal nu onlangs geschied in de veertig communiceerende ledematen waren geronden geweest, hetwelk bij deze harde en ongehoorde verrolginge dagelijks meer on meer stond toe te nemen"; reden genoeg, meenden zij, om hun verzoek te wettigen, dat de resolutie werd ingetrokken en aan die ran Sas machtiging werd verleend Correge te beroepen en to bevestigen. Naar aanleiding van dit request gaf de Raad van State den 27 November 1685 aan de Staten-Generaal in bedenken of het niet wenschelijk zoude wezen „dat Ds. Corrége beroepen werd om zijn functie waar te nemen op het Sas, en dat bovendien nog een predikant beroepen werd tot Oostburg", dit laatste met het oog op het aanzienlijk getal Franschen, dat zich reeds te Oostburg berond on ongetwijfeld nog van dag tot dag stond to vermeerderen, en door wier "confluentie de middelen tegenwoordig merkelijk hooger waren verpacht en successivelijk meerder gebeneficieerd zouden worden" 1 ). Aan dien raad gaven de Staten-Generaal ten deele gevolg: den 15 December 1685 bepaalden zij dat Corróge met den roorlezer weder naar Sas van Gent zouden worden overgeplaatst.

Intusschen had zich te Oostburg een gerefugieerd pasteur uit Frankrijk gevestigd, met name Samuel Georges. Georges, die laatstelijk het leeraarsambt bekleedde to Vitry-leFrançois in Champagne, tusschen Rheims en Troyes, had zich daar op een goeden dag van de maand Februari 1685 van den kansel wat al te vrij uitgelaten over de kwellingen, welke de Hugenoten te verduren hadden ${ }^{2}$ ). Van die preek werd door de Roomschen zooveel ophef gemaakt, dat de kerkeraad van Vitry zich uit vrees voor de gevolgen verplicht achtte den pasteur te censureeren. Het koninklijk

1) Brief van den Raad van State aan de Staten-Generaal van 27 November 1685. Met de "middelen" zijn bedoeld de landsbelastingen, welke ieder jaar werden verpacht

2) Haag, France Protestante, i. v. Samuel Georges. 
decreet, waarbij verordend werd dat alle Hervormde kerken, waar "oproerige" predikatiën waren gebouden, gesloopt moesten worden ${ }^{1}$ ), was destijds nog niet uitgevaardigd misschien, zegt de geschiedschrijver, wiens verbaal wij hier volgen, is Georges' preek wel de aanleiding geweest die het heeft uitgelokt. Niettemin sprak de rechter over Georges' ambtgenoot Varnier een vonnis uit en gaf hij bevel de kerk te sluiten onder betzelfde voorwendsel, waarvan in dat decreet gesproken wordt, te weten omdat Varnier zijn collega onder diens preek niet tot de orde had geroepen. Doch nu de censuur, door den kerkeraad aan Georges opgelegd, den beoogden slag dreigde af te wenden, sloeg de Roomsche partij een anderen weg in. Zij trachtte bewijzen te vinden, dat Georges herhaaldelijk zulke preeken had gehouden zonder dat de kerkeraad er hem over had berispt, en het gelukte haar een priester te vinden die alles getuigde wat zij maar verlangde. Jammer genoeg was er voor dergelijke vergrijpen nog geen straf bepaald, zoodat men ook nu nog geen rat op Georges en zijn gemeente kon krïgen. Dat was echter geen bezwaar. Om haar doel te bereiken voegde de tegenpartij er een tweede beschuldiging bij, die uitsluitend berustte op een onbewezen gissing. Een van de ouderlingen, door wien het toezicht werd gehouden op degenen die de kerk binnentraden, had bij zekere gelegenheid een vrouw geweerd, welke hem verdacht voorkwam. Door een van haar familieleden gevraagd of hij dat op order van den kerkeraad had gedaan, antwoordde hij van neen, maar eenige priesters gingen het geval aangeven,

1) Bedoeld is blijkbaar de „Déclaration du Roy” van 18 Juni 1685, waarin onder meer voorkomt het volgende: ${ }_{n}$ voulons en outre que les temples, dans lesquels il sera fait des prêches séditieux en quelque manière que ce soit surtout au sujet des édits, déclarations ou arrêts, qui ont été et qui seront par Nous rendus concernant la Religion Prétendue Réformée, soient pareillement démolis, et l'exercice interdit pour jamais dans les villes et lieux oú lesdits temples sont situés, et ce lorsque les autres ministres et anciens, qui auront élé présens ou assisté auxdits prèches, ne s'y seront point opposez pour justifier", bij Pilatte, Edite, declarations et arrests concernant la religion prétendue réformé, Paris 1885, p. 197. 
en nu bestond er voor den rechter geen twijfel meer of het besluit om de vrouw den toegang tot de kerk te weigeren was wel degelijk van den kerkeraad uitgegaan. Het geval was rolgens hem des te erger, daar het besluit niet in de kerkeraadsnotulen was opgeteekend en bügevolg genomen moest wezen in de afwezigheid van den koninklïken commissaris, door wien de zittingen van den kerkeraad moesten worden bïgewoond. $\mathrm{Nu}$ was men ver genoeg om aan wat men roorhad een glimp van wettigheid te geven; toen de zaak voor het parlement van Parijs in behandeling kwam, hield de procureur-generaal in zijn eisch staande dat het niet roldoende was den schuldige to treffen maar dat terens de kerk, waar Georges zijn ambt had misbruikt, naar rechte behoorde te worden afgebroken, ook al was het zoo dat er op dit tïdstip nog geen wet bestond, door welke die straf was bepaald. Immers, zoo zeide hij, bet preeken in oproerigen geest wordt noch door goddelijke noch door menschelijke wetten gedoogd ${ }^{1}$ ). Werkelijk is daarop de kerk van Vitry gesloopt geworden, en ontkwam Georges alleen door de vlucht aan de galeistraf. Zijn dochter, die hij in Frankrijk had moeten achterlaten, werd in een klooster opgesloten waaruit $z \mathrm{ij}$ eerst acht jaar na haar vaders overlijden wist te ontsnappen ${ }^{2}$ ).

Met Georges woonden er in Oostburg verscheidenelidmaten van zïn vorige gemeente ${ }^{3}$ ) on op hun verzoek hield bï nu na Correge's vertrek van tijd tot tijd Fransche godsdienstoefeningen, bij een van welke, gelijk hij zelf den 31 December 1685 verklaarde, niet minder dan honderdvïftien hoorders aanwezig waren ().

De groote menigte réfugiess uit Noord-Frankrïk, die zich in hun midden ophield, en de zucht om er nog meer herwaarts to trekken, bewoog de heeren van den magistraat in het begin van Januari 1686 andermaal een

1) Benoist, Hist. de $l$ Edit de Nantes, Delft 1693-1695, III, p. 762.

2) Haag, France Protestante, i. v. Samuel Georges.

3) Zoo althans beweert de magistraat zelf in zijn request aan de StatenGeneraal ran 3 Januari 1686.

4) Blijkens zijn verklaring bij evengemeld request overgelegd. 
beroep te doen op de hooge regeering in den Haag. Het was, zoo schreven zij aan de Staten-Generaal, voor de Oostburgsche vluchtelingen ondoenlijk om in de Waalsche van Groede hun godsdienstplichten waar te nemen vanwege den slechten weg, die bij winterdagen te nauwernood met paarden te berijden en voor voetgangers slechts zelden begaanbaar was. Bovendien moesten zij onderweg een veer passeeren, dat hun voor elke heen- en terugreis twee stuiver de man kostte 1). Ook badden zï wegens den afstand bijna geen tijd om in Groede te wezen roor de ochtendpreek, en $\$ z 00$ wanneer dezelve in de Groede kwamen, waren (zij) nog genoodzaakt te gaan in een herberge om vuur aan te laten leggen, dat maar van eenige weinige somtijds kon worden gedaan die nog iets uit Frankrijk hadden medegebracht, maar werden het tegenwoordig zoo moede dat zij het niet meer zeiden te kunnen doen omdat zij, zes dagen in de week gearbeid hebbende om hun kost te winnen, op den dag des Heeren gaarne zouden rusten, en van den arbeid van die gansche week zooveel niet konden overhebben om hun reergeld te betalen". De magistraat smeekte daarom, dat hun Hoog Mogenden vergunning wilden geven om Ds. Georges voor de Waalsche gemeente te Oostburg te beroepen met en benevens een Franschen schoolmeester-voorlezer, beiden op een vast tractement. Om de Staten gunstig roor hun aanvraag te stemmen, wezen zij er op dat een Waalsche kerk ten hunnent tegelijk ook kon dienen voor die réfugiess, die zich omtrent Schoondïke en IJzendijke hadden nedergezet, terwijl de uitgaven, welke de bezoldiging van pasteur en voorlezer voor den Staat medebrachten, hun inziens gedekt zouden worden door de vermeerdering van de opbrengst der landsimposten, die mettertijd van de overkomst der vluchtelingen to verwachten was. ${ }^{2}$ ).

Zoo gunstig als de beschikking ook was, door de

1) Bedoeld is het veer bij Scherpbier.

2) Request van den magistraat aan de Staten-Generaal van 5 Januari 1636. 
Staten-Generaal op het request genomen - de gevrangde machtiging tot het beroepen van een predikant en roorlezer werd op 14 Januari 1686 verleend - zij liet 6én gewichtig punt onbeslist, de regeling namelijk van hun tractement. Alleen droeg zij aan den Raad van State de taak op om over dit onderwerp de roorlichting in te winnen van den Oostburgschen magistraat en den ontvanger der geestelijke goederen, en vervolgens in overleg te treden met een commissie ad hoc uit de Staten-Generaal, opdat dezen na bekomen rapport een nadere beslissing zouden kunnen nemen ${ }^{1}$ ). De Raad van State op zija beurt droeg de hem opgedragen taak over aan zijn Gedeputeerden, die in het aanstaande roorjaar een bezoek aan Staats-Vlaanderen zouden brengen ${ }^{2}$ ). Vóór Maart, den tijd waarop de Gedeputeerde Staten gewoonlijk in Staats-Vlaanderen aankwamen, viel dus op afdoening van de zaak niet te rekenen.

Doch éen ding hadden de Oostburgers al vast gewonnen: het recht om een Waalsche predikant en voorlezer te benoemen, was hun, gelijk wij zagen, met zooveel woorden toegestaan. Toch durfden zij blïkbaar van die beroegdheid alsnog geen gebruik maken. Immers den 14 Februari 1686 dienden $z \ddot{y}$ wederom een request in om met den eersten met de beroepinge van een Fransch predikant en het aanstellen van een Fransche schoolmeester en roorlezer te mogen roortgaan". Het geduld van de Hugenoten raakte uitgeput, heet het daar, en zij begonnen reeds de hoop op te geven van ooit de erangelieverkondiging in hun moedertaal te zullen hooren - waarschijnlijk vertoefde Ds. Georges op dit tijdstip niet meer te Oostburg, zoodat de vluchtelingen weer geheel van Fransche godsdienstoefeningen verstoken waren ${ }^{3}$ ), - en in arren moede wierpen z z aan den magistraat en kerkeraad zelfs het verwijt voor de roeten, dat die hen „maar alleen met beloften opbielden", ja het stond te vreezen, voegde het request er bij,

1) Resolutie Staten-Generaal 14 Januari 1686.

2) Resolutie Raad van State 18 Januari 1686.

3) Zie beneden. 
dat de meesten van ben binnenkort uit Oostburg zou-

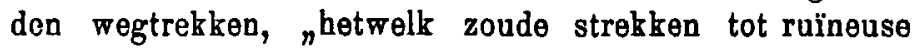
schade van de stad" en bijgevolg "tot merkelijke schade van de gemeene landsmiddelen '), die anderszins aldaar stonden merkelijk te vermeerderen" "). Zoo de magistraat, ofschoon er in dit request met geen woord van werd gerept, de stille hoop heeft gevoed, dat de regeering in den Haag, in afwachting van hetgeen later definitief zou worden bepaald, nu al roorloopig van landswege aan den aan te stellen pasteur en roorlezer een tractement zou toeleggen, dan moet de beschikking door de Staten-Generaal op dit verzoekschrift genomen nieuwe teleurstelling bij hem hebben opgewekt. Want al handhaafden de Staten hun besluit van 14 Januari, zij lieten ook thans de tractementsquaestie weer geheel onbeslist. Alleen verordenden $z \ddot{y}$, dat de Raad van State door zijn eerstdaags naar Staats-Vlaanderen vertrekkende Gedeputeerden een onderzoek zou laten doen naar ${ }_{n}$ den toestand en de gelegenheid van de Fransche gemeenten aldaar", alsmede nof niet eenig, en uit wat middelen, een fonds gevonden zou kunnen worden, waaruit eenige predikanten aldaar zouden kunnen worden onderhouden, en op wat plaatsen dat die tot dienst van de voorschreven Fransche gemeenten behoorden te worden geemployeerd" 3).

Hoe het zij, op aandrang van een tweetal afgevaardigden der Waalsche Synode, ging eindelïk de magistraat er toe over om de Fransche gemeente op vasten voet te organiseeren. Den 28 Februari 1686 belegde hij een zoogenaamd n collegium qualificatum", dat de gemeente voor gevestigd verklaarde en een kerkeraad anstelde. Nog dien eigen dag rerkoos de Waalsche kerkeraad zekeren Noé de Laval tot voorlezer en beriep Ds. Georges, die destijds al niet meer te Oostburg maar te Middelburg verblijf hield, tot pasteur $\%$.

1) Dat is: de verpachte belastingen.

2) Request van den kerkeraad en magistraat aan de Staten-Generaal van 14 Februari 1686.

3) Resolutie Staten-Genoraal 15 Februari 1686.

4) Dresselhuis, Waalsche gemeenten in Zeeland, Bergen op Zoom 1848, blz. 69 ; Ferbaal Vlaanderen Raad van State voorjaar 1686. 
Toen Ds. Georges den 31 Maart 1686 tot zijn dienstwerk werd ingeleid ${ }^{1}$, waren de Gedeputeerden van den Raad van State bereids in Staats-Vlaanderen aangekomen. Zij lieten zich door de stedelijke regeeringen van Aardenburg en Oostburg een lijst overhandigen van de gevluchte Hugenoten, die zich daar hadden gerestigd, met opgaaf ran het beroep dat door hen uitgeoefend werd, en namen een tweetal verzoekschriften in ontrangst, een ran den Groedschen Walenpasteur de Brunville en Daniel Bosberge, Waalsch ouderling te Oostburg, die hun uit naam der. Waalsche Synode om een acte van tractement verzochten ten behoere van Georges en de Laval, en een tweede, hun door Ds. Georges zelf aangeboden. Laatstgenoemde deelde hun in zijn request mede, dat hij ngeweest was een persoon van tamelijke middelen, welke nu als uit Frankrïk gebannen zijnde alle waren geconfiskeerd, en dat hï niet het minste van waardije had kunnen uitbrengen". Om die reden bad hij de Gedeputeerden, dat zij den ontvanger der geestelijke goederen van Oostburg $n^{\text {zouden }}$ willen ordonneeren om eenig pensioen aan hem te geven tot zijn onderhoud, alzoo hij geen middelen hebbende het onmogelijk was om te Kunnen bestaan" ").

De Gedeputeerden, die in dezen niet eigenmachtig konden beslissen, namen de requesten mede naar den Haag om ze aan den Raad van State over te leggen. Niettemin trachtten zij door hun invloed to bewerken dat aan Ds. Georges eenige onderstand werd geschonken. „Wij hebben (zeggen zij in hun verbaal) den wayistraat van Oostburg ${ }^{3}$ ) gerecommandeerd, zoo het mogelijk ware, denzelven predikant uit de stadswiddelen bij provisie eenige assistentie te doen, alzoo wï verstonden dat denzelven een man was van goede reputatie" ").

1) Zoo vermeldt hij zelf in een request aan de Staten-Generaal van 6 Juni 1686.

2) Verbaal Vlaanderen Raad van State, voorjaar 1686 .

3) In het verbaal staat abusievelijk : Aardenburg.

4) Perbaal als roren. 
Bij hun terugkeer in den Haag, omstreeks balf April, waren de Gedeputeerden nog niet in staat eenigerlei inlichting te rerschaffen nopens bet andere punt, waarover hun opdracht liep, de vraag namelijk hoe er een fonds zou kunnen gevonden worden tot het bezoldigen van de Waalsche predikanten in Staats-Vlaanderen 1). Omtrent een maand later ${ }^{8}$ ) echter was den Raad van State reeds een memorie in handen gekomen, waarin de Oostburgsche magistraat een oplossing aan de hand deed, die er verleidelïk genoeg uitzag. Ingeval soms de hooge regeering zwarigheid màakte om de gelden te verstrekken, welke roor het bekostigen der Fransche godsdienstoefeningen te Oostburg werden vereischt en die naar zijn berekening over tractementen als anderszins achthonderd gulden jaarlijks beloopen zouden, zoo bestond er een uiterst gemakkelijk middel, meende de magistraat, um deze som bijeen te krijgen zonder dat er de Staat een penning voor uitgaf. Hij maakte zich namelijk sterk, dus gaf hij te kennen, om bet beweerde maar ongefondeerde recht van de St. Pietersabdij te Gent op de tienden $\nabla a n$ den nieuwbedjikten Brugschevaartpolder ${ }^{3}$ ), en de polders Henricus en Stampershoek, welke door genoemde abdij werden geheren, nzoodanig te ontdekken" dat de regeering in den Haag $n$ daarran sommige aanstonds, andere na gedaan vertoog van de onrechtraardige bezittinge, in possessie zoude kunnen krïgen, en welke tienden jaarlijks zouden meer bedragen als veertienhonderd guldens, zijnde bijna eens zooveel als de Fransche kerk tot Oostburg zou komen te kosten". En zelfs al ware de abdij tot die tienden gerechtigd, ook dan nog (merkte de magistraat op) rustte op haar de onafwijsbare verplichting om uit de opbrengst het predikants- en schoolmeesterstractement te betalen, op denzelfden roet als zij dit to

1) In het verbaal toch, na hun terugkeer aan den Raad van State overgegeven, wordt van deze zaak met geen enkel woord gewag gedaan.

2) Blijkens resolutie Raad van State 27 Mei 1686.

3) Bedijkt op octrooi van 7 Maart 1684. 
Schoondijke deed uit de tienden, welke zij onder die parochie hief 1).

Eindelijk, nadat Georges en de Laval opnieuw hun nood hadden geklaagd en zoowel de magistraat als de Waalsche kerkeraad op bespoediging badden aangedrongen ${ }^{2}$ ), werd de zaak den 8 Augustus 1686 roor goed afgedaan: de Raad van State legde den pasteur een salaris toe van vierhonderd gulden met nog honderd gulden voor huishuur en den voorlezer een van honderd gulden, niet echter uit de Oostburgsche tienden der Gentsche abdï maar uit een bijzonder fonds, in de maand Juli 1686 door de Staten-Generaal te zijner beschikking gesteld voor de bezoldiging van eenige gerefugieerde predikanten, en tot welks vorming van elken gulden, dien de verponding ${ }^{3}$ ) in Staats-Vlaanderen en de overige Generaliteitslanden opbracht, én oortje moest worden afgezonderd 4 ), en eenigen tijd later hechtte de Raad zijn goedkeuring aan de beroepen omtrent een half jaar te poren op Georges en de Laval uitgebracht ${ }^{5}$ ).

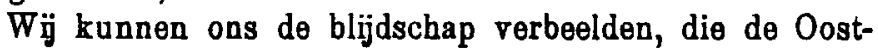

1) Blijkens de Memorie voor $d^{\prime}$ heeren Gedeputeerdens zoo van haar Ho. Mo. als d' Edel Mo. Raden van State tot de besogne van het verleenen van cen Franschen predikant en schoolmeester voor de stad Oostburg. Het stuk bevindt zich onder de requesten aan de StatenGeneral van 1686; het is ongedateerd dooh blijkbaar reeds vóor 27 Mei 1686 bij den Raad van State bekend geworden, op welken datum de Raad het advies van een van 's lands adrocaten op "het subjeot van het uitvinden van een tractement" voor die beiden " ${ }^{\text {uit de tienden }}$ van St. Pieters nevens Gent" ten fine van rapport in banden stelde van den ontvanger der Oosthurgsche kerkegoederen.

2) Request van Georges on de Laval aan de Staten-Generaal van 6 Juni 1086 . $Z_{i j}$ vermelden daarin, dat $2 i j{ }_{n}$ door het vluchten uit Frank rijk alles hebben moeten abandonneeren en nu niets overig hebben orn to subsisteeren"; Request van den magistruat aan de Gedeputeerden der Staten-Generaal in Staats-Vlaanderen van 5 Juli 1686 en van den Kerkeraad aan de Gedeputeerden van don Raad oan State van het najaar van 1686 (beide opgenomen in de respectieve verbalen).

3) Ongeveer hetzelfde ais onze belasting op gebou wde en ongebouwde eigendommen.

4) Resolutie Staten-Generaal 25 Juli 1686.

5) Verbaal Vlaanderen Raad van State najaar 1686. 
burgsche Hugenoten en hun leeraar zal hebben vervuld, toen zij eindelijk na langdurig wachten en pijnlïke onzekerheid hun wensch verkregen hadden. Een omstandigheid nochtans moest de vreugde temperen. Zoolang zij geen eigen kerkgebouw bezaten, moesten zij zich bedienen van dat der Nederduitsche gemeente, waarin zij slechts énmaal per Zondag tusschen de Hollandsche predikatiën in, godsdienstoefening konden houden. Het strekt de nagedachtenis der arme bannelingen tot eere dat zij reeds in het voorjaar van 1687 druk bezig waren om uit eigen middelen een fonds te formeeren, dat hen door het stichten van een eigen bedehuis tot verbetering van dien toestand in staat zou stellen. Onvermogend om zelf een toereikend bedrag te vergaderen hielden $z$ ij bij den magistraat om eenige ondersteuning uit de stadskas aan, die hun voor het goede doel eenige olmeboomen afstond, welke hij indertijd op het kerkhof had aangeplant. Doch spijtig genoeg wees de Raad ran State, van wien zij voorzichtigheidshalve verlof vroegen om de boomen te verkoopen, daar het twijfelachtig was of deze aan de stad dan wel aan het kantoor der geestelijke goederen behoorden '), het verzoek van de hand ${ }^{2}$.

Werd dientengerolge de uitroering van hun plan eenigszins vertraagd, nadat $z$ ij door schenking in het bezit waren gekomen van een aan de Markt gelegen "plein van een oud huis", waarvan de zij- en achtermuren nog overeind stonden ${ }^{3}$ ), konden zij tot den bouw van hun kerkje overgaan. On de achthondervïftig gulden te vinden, waarvoor het in Mei 1688 aan den timmerman Daniel Bekkens werd aanbesteed 4 ), namen de lidmaten de verplichting op zich dat zij bij elke Arondmaalsviering, de eene én en

1) Dit kantoor werd ran wege den Raad van State door cen ontvanger beheerd.

2) Verbaal Flaanderen Raad van State voorjaar 1687.

3) Verbaal als voren najaar 1700, en bijlage no. 16 van het $V e r-$ baal Vlaanderen Staten-Generaal van 1689.

4) Bericht van Bekkens, overgelegd bij het request van de ouderlingen Jean Sauvage en David dmeau aan do Staten-Generaal op 7 Mei 1699. 
de andere twee schellingen, zouden bijdragen ${ }^{1}$ ), maar toen in den nazomer bet gebouwtje onder dak was ${ }^{2}$ ), ontbraken de middelen om het binnenwerk te bekostigen. In de hoop dat het tekort door den Raad van State uit de inkomsten der Nederduitsche kerkgoederen van de stad zou worden aangevuld, dienden de Walen een request bij dezen van die strekking in en riepen, nadat daarop een afwijzende beschikking was gevallen ${ }^{3}$ ), in het voorjaar van 1689 andermaal de hulp van den Raad in. $\mathrm{Zij}$ rertoonden aan diens Gedeputeerden, toen die in Maart 1689 in Staats-Vlaanderen arriveerden, hoe aan de kerk nog „maar alleen mankeerden de glazen, predikstoel, ouderlingen-en diakenenbochten, tuin en vloer hetwelk bij hen, boe weinig zulks zou komen te importeeren, niettemin die kleene somme niet kon worden uitgevonden om op gelijke payementen besteed te worden, alzoo geen aannemer daar te vinden was" "). $0 \mathrm{~m}$ aan deze som, rolgens de inlichtingen door de Gedeputeerden ingewonnen slechts het luttele bedrag van driehonderd gulden bedragende "\%, te kunnen komen, verzochten zij een toelage uit de middelen van de Nederduitsche kerk ten hunnent, of wel verlof om eenige oude boomen, die op het kerkhof stonden, te hunnen bate te mogen verkooopen $\left.{ }^{\circ}\right)$. Ditmaal werd hun bet gevraagde niet geweigerd. Bij besluit van 31 Mei 1689 stond de Raad van State hun den rerkoop van de boomen toe en bepaalde tegelijk dat, als deze niet genoeg opleveren zou, het ontbrekende uit de inkomsten ran Oostburg's kerkegoederen zou worden bijgepast.

Onder al die bedrïren had de kerkeraad, nadat Ds.

1) Request van Sauvage en Ameau aan de Gedeputeerden van de Staten-Generaal in 1689.

2) Terbaal Flaanderen Raad van State najaar 1688 en voorjaar 1689.

3) Verbaal als voren najaar 1688.

4) Verbaal als voren voorjaar 1689.

5) De ontvanger der Oostburgsche kerkegoederen Johan Goris raamde ten naaste bij noodig : voor de glazen 50 , voor den vloer 66 , den predikstoel en de grenenhouten banken 151 , voor ijzerwerk 40 gulden; Verbaal als voren roorjaar 1689.

6) Ferbaal als voren voorjaar 1689. 
Georges in Februari 1687 overleden was, uit een twaalftal door den Raad van State aanberolen pasteurs tot diens opvolger gekozen den voormaligen predikant van Bugnein in Bearn, Isaac Campagne. Hoewel de Synode de handelwäze van den kerkeraad scherp laakte en de kerken met nadruk op het hart drukte het voorbeeld van de Oostburgsche gemeente niet te volgen, maar bij het uitbrengen van ordinaris-beroepen de gewone manier van doen in acht te nemen, heeft zij ten slotte uit aanmerking ran de gunstige getuigenissen, die zij omtrent Campagne ontring, de verzochte goedkeuring niet geweigerd 1), maar zijn berestiging in Mei 1687 onverhinderd laten voortgaan 2).

Niettegenstaande de gemeente hoofdzakelijk uit réfugies bestond bleef men tot in Campagne's tijd steeds de kerke. raadsleden uit die lidmaten verkiezen, welke oorspronkelijk tot de Nederduitsche kerk hadden behoord maar bij de oprichting van de Waalsche tot deze laatste waren overgegaan. Aan dat gebruik werd een einde gemaakt door het kerkeraadsbesluit van 25 Augustus 1688, inhoudende dat voortaan bij vacatures ook uit de réfugiés naar verhouding van hun aantal ouderlingen en diakenen zouden worden benoemd.

Ruimde men zoo doende een struikelblok uit den weg, waardoor de gezonde ontwikkeling van het kerkelijk leven werd belemmerd, de nieuwe regeling belette niet dat er in de lente $\operatorname{van} 1689$ een tweespalt in de gemeente oprees zoo groot, dat voor een oogenblik zelfs haar voortbestaan gevaar liep. $Z_{i j}$ was hoofdzakelijk een gevolg hierran, dat Campagne twee nieuwe kerkeraadsleden weigerde te bevestigen, die omstreeks balf April 1689 waren verkozen 3 ). Welke redenen bij voor zijn weigering ook moge gehad hebben, zij werden niet gedeeld door de andere broederen ran den kerkeraad, zooals blükt uit den lastbrief, met welken $z \ddot{j}$ op het laatst $\operatorname{van}$ Augustus

1) Synode Middelburg Aprit 1687, art. 7 (Liore Synodal, II, p. 24).

2) Bulletin, III, p. 324.

3) Synode I'lissingen Augustus 1689, art 18 (Livre Synodal, II, p. 73). 
een van de hunnen ter Synode afvaardigden. $Z_{i j}$ droegen hem op van de hooge vergadering order te vragen, vooreerst dat de beide gekozenen in hun ambt zouden bevestigd worden, als zijnde wettig overeenkomstig de kerkenorde en met goedkeuring van den magistraat benoemd; ten tweede dat de besluiten, met meerderheid van stemmen door den kerkeraad genomen, ingeval van daar tegen ingebrachte klachten bij voorraad ten uitroer zouden moeten gelegd worden tot op de bijeenkomst der naastvolgende Synode, waar zij dan zoo noodig zouden worden geredresseerd 1); in de derde plaats dat het Arondmaal ten hunnent zou moeten worden bediend overeenkomstig de gewoonte, welke in de Nederlanden in zwang was, te meer omdat de wijze, waarop het tot dusver door Campagne bediend werd, sommige lidmaten van deelneming terughield, die den wensch hadden te kennen gegeren dat tot hun vertroosting en stichting bij de plechtigheid het gebruik van alle andere Waalsche kerken zou worden gerolgd ${ }^{2}$ ); en eindelijk dat de Synode een reglement zou vaststellen op den predikdienst in hun gemeente en bepalen zou, dat Campagne elken Zondag tweemaal moest optreden en, zooals overal elders gebeurde, vóór de A rondmaalsviering huisbezoek doen ${ }^{3}$ ).

De Syaode begreep het twistruur aanstonds met alle middelen te moeten uitdooven. $\mathrm{Z}_{\mathrm{ij}}$ bracht Campagne onder het oog dat $z$ ij zijn gedragslijn in geenen deele billijken kon, bewoog hem zijn tegenstand te laten varen, bepaalde dat de beide benoemden, als zijnde personen van wie erkend werd dat zij alleszins bekwaam waren om bun bediening tot stichting der gemeente te bekleeden, ten spoe-

1) nera exécuteé par provision jusques à la tenue du Synode en cas qu'il y ait quelque partie plaignante, où la chose pourra estre redressée".

2) „D'autant plus qu'à cause de la manière dont Monsieur Campagne l'a administrée jusque $\mathfrak{a}$ ce jour, il y a eu des membres qui se sont abstenus de la Sainte Céne, et qui demandent qu'on leur donne la consolation de l' administrer comme dans toutes nos églises".

3) De lastbrief of instruction van den kerkeraad is opgenomen in de Actes et papiers originaux van de Synode van Vlissingen van Augustus 1689. 
digste zouden bevestigd worden, en wist op de vergadering zelve tusschen Campagne en den nieuwgekozen ouderling een verzoening te bewerken. En opdat de herstelde vrede des te duurzamer zoude wezen, droeg de Synode haren voorzitter op om zich gezamenlijk met den pasteur van Groede naar Oostburg te begeven, teneinde de bevestiging der beide kerkeraadsleden te verrichten en door hun vermaningen alle zaden van twist en tweedracht uit de gemoederen weg te nemen. Zij zouden verder, tot voorkoming van verdere oneenigheden, dé zaken hebben te regelen op den volgenden voet: besluiten van den kerkeraad zouden van kracht blijven tot op de eerstrolgende vergadering der Synode; bij het Avondmaal, dat op dezelfde wijze moest gevierd worden als op andere plaatsen, zou de pasteur aan iedere tafel een bijzonderen zegen uitspreken; vóór elke A rondmaalsvieríng zou hij met een van de ouderlingen huisbezoek doen, en verder zou hij, niet in staat zijnde alle Zondagen twee predikatiën te doen, des Zondags namiddags zooveel zijn gezondheid dit toeliet catechizatie voor de kinderen houden 1).

Wat Campagne, die in 1690 overleed, nog te regelen had overgelaten, werd onder het pastoraat van zijn opvolger François Dural met ijver ter hand genomen. Men legde registers aan van de bedeelden en van de lidmaten; besloot nauwkeuriger toezicht te houden op het geestelijk welzijn van de bedeelden en de oproeding der weeskinderen ${ }^{2}$ ); bepaalde dat bij de binnen de stad gevestigde lidmaten vóór elk Arondmaal en bij de buiten wonenden ónnmaal in het jaar huisbezoek zou gedaan worden ${ }^{3}$ ); trof maatregelen tegen het misbruik dat bij do doopsbediening getuigen optraden, die geen lidmaat of zelfs Roomsch waren, gelijk meermalen voorkwam ${ }^{4}$ ); verordende dat degenen, die uit het pausdom tot de gemeente overgingen, voortaan, aleer

1) Synode Vlissingen, Augustus 1689 (Livre Synodal, II, p. 73).

2) Kerkeraadsacta, 22 October en 17 December 1690, 3 Mei 1693.

3) Als voren, 17 December 1690.

4) Als voren, 17 December 1690.

X. 
zij werden angenomen, eerst in het openbaar belijdenis van hun geloof hadden te doen 1); voerde om de verregaande onwetendheid weg te nemen van velen, die als lidmaten wenschten te worden toegelaten, catechizatiën in ${ }^{2}$ ); schafte een zegel aan om de bewijzen ran lidmaatschap te stempelen ${ }^{3}$; regelde de schoolzaken ${ }^{4}$ ); stelde iemand aan om te beletten dat er gedurende de godsdienstoefeningen vó́r de kerk rumoer werd gemaakt ${ }^{5}$ ) - verzuimde in én woord niets dat den welstand der gemeente bevorderen kon.

Om dit oogmerk te bereiken werd tevens, zoo dikwijls de gelegenheid zich voordeed, de geldelijke steun ingeroepen van de hooge regeering in den Haag. Zoo trachtten bij de beroeping van Dural in 1690 kerkeraad en magistraat beiden de jaarwedde van den pasteur van vijfhonderd tot zeshonderd verhoogd te krijgen ${ }^{6}$ ). Beter dan met dit voorstel, dat door den Raad van State werd afgewezen ${ }^{7}$ ), slaagde men in het volgend jaar met een verzoek om een jaarlüksche bïdrage van vïfentwintig gulden voor bet bekostigen van de verwarming en verlichting voor de kerkeraadsvergaderingen, die bij gebreke van een consistoriekamer aan het huis van den predikant werden gehouden ${ }^{8}$ ). In Juli 1698 schonk de Raad van State den predikant op zijn aanvraag een extra-toelage van zestig gulden 's jaars voor huishuur ${ }^{9}$, na reeds een paar maanden vroeger voor den

1) Als voren, 30 Juni 1691.

2) Als voren, 20 Januari 1692. Bedoeld zijn blijkbaar catechismuspredikatiēn.

3) Als voren, 5 Augustus 1696. Het zegel, zooals het voorkomt op een afdruk in lak in de verzameling kerkelijke zegels op het Rijksarchief te 's Hage, vertoont een vrouw, met het anker der hoop steunende op een rots, en het omschrift: Christus rupes salutis. Sigillum ecclesize wallonicae Oostb.

4) Als voren, 3 Mei 1693, 7 Maart 1695, 9 December 1696.

5) Als roren, 13 April 1696.

6) Als voren, 17 September 1690 .

7) Resolutie Raad oan State 20 November 1690.

8) Kerkeraadsacta, 24 Juni 1691, en Resolutie Raad van State 15 Mei 1698 (Verbaal tienden Vlaanderen).

9) Resolutie als voren 25 Juli 1698 (Verhaal als roren). 
aankoop van brood en wijn bij het Avondmaal een jaarlijksche gift van vïftig gulden te hebben toegezegd 1).

Als reden, welke hem tot het aanvragen van deze laatste som noopte, had de kerkeraad opgegeven, dat het noodig was in plaats van eenmaal, zooals in de andere naburige Walenkerken geschiedde, to Oostburg twee keer in het jaar A rondmaal te houden, niet alleen vermits de lidmaten "wijd en zijd verspreid" woonden, maar omdat de gemeente in den laatsten tijd sterk in ledental toenam. Aanvankelijk, naar het schijnt, alleen aangroeiend door de aanneming van catechizanten en dan nog vermoedelijk niet in aanzienlijke mate, nu en dan ook door de toetreding van enkele bekeerde Roomschen ${ }^{2}$ ), was de gemeente zooals de kerkeraad bet in zijn request van 1698 uitdrukte, destïds ${ }_{n}$ alle dagen toenemende door de toevlucht van verscheidene broeders uit Walschland en Frankrijk" 3). Stellig zijn er onder die overgekomen Franschen verscheidenen geweest, welke eerst te Oostburg tot het Protestantisme overgingen, immers in April van het volgende jaar besloot de kerkeraad ook diegenen in de gemeente op te nemen, die uit Frankrijk kwamen en, ofschoon Roomsch, wenschten toe te treden, indien er ten minste op hun levensgedrag niets viel aan te merken 4 ).

Evenwel was het, gelïk uit zijn notulenboek blïkt, in den grond niet zoozeer de noodzakelijkheid van een tweede avondmaalsviering, die den kerkeraad tot het verzoek om subsidie bewogen had. Zij werd slechts als voorwendsel gebruikt om een som te verkrijgen, waaruit de reis- en verblijfkosten konden gevonden worden van den afgevaardigde naar de Synodale vergaderingen ${ }^{5}$ ), voor welke men al

1) Resolutie als voren 15 Mei 1698.

2) Het getal van de aannemelingen bedroeg rolgens het "Regitre des communians" (1691-1714) respectievelijk in 1692:3, 1693: 4, 1694: geene, 1695: 7, $1696: 5,1697: 2,1698: 2,1699: 2,1700: 3$ personen; dat van de proselyten uit het pausdom in 1692 en 1693 geen, $1694: 3$, $1695: 8,1696: 4,1697: 2,1698: 7,1699: 11,1700: 13$ personen.

3) Verbaal Vlaanderen Raad van State roorjaar 1698.

4) Kerkeraadsacta, 29 Maart 1699.

5) Als voren, 9 Maart 1698. 
herhaaldelïk doch vruchteloos zoowel bij den magistraat als bij den Raad van State bad aangeklopt 1).

Behoefde alzoo de kerk voor haar eeredienst en dergelïke aanhoudend finantieelen onderstand van den staat, de verzorging van haar armen en weezen werd haar vergemakkelijkt door het legaat van zekeren Jacques Hugeux, die omstreeks 1694 zijn geheele nalatenschap ten bedrage van eenennegentig pond grooten aan de diaconie vermaakte ${ }^{3}$, waardoor deze in staat werd gesteld om in November 1694 een partij land in den Veerhoekpolder aan te koopen tegen den prijs van vijftien pond het gemet ${ }^{3}$ ). Al dadelijk kwam de vermeerdering van inkomsten aan de kinderen ten goede, wier ouders zich do kosten van hun onderwijs niet konden getroosten, daar de kerkeraad in Maart 1695 het schoolgeld van dezulken voor zijn rekening nam ${ }^{4}$ ). Hugeux' voorbeeld werd omtrent twintig jaar later gevolgd door zekeren Jean de Busse, wiens boedel ter grootte van honderdzerenenveertig pond tusschen 1715 en 1719 onder beheer van de diaconie kwam ${ }^{5}$ ). Nadat in Mei 1721 een afzonderlïke ontranger voor de Armenpenningen was aangesteld, ${ }^{6}$ ) ontring de diaconie in 1734 wederon een legaat van Joseph Cagnet, die haar een som van tweehonderd gulden vermaakte, ${ }^{7}$ ) en in 1738 opnieuw een van zekeren Portois(?), door wien zij tot universeel erfgenaam werd benoemd ${ }^{8}$ ).

Ter verranging ran Dural, die te Oostburg overleed, werd op het laatst van 1705 tot pasteur beroepen Lénard Fauchereau, tot dusver veldprediker bij een Staatsch regiment, die in October zijn intrede deed ${ }^{9}$ ). Na gedurende vijf jaar

1) Als roren, 26 November 1693 en 25 Augustus 1699.

2) Als voren, 18 A pril, 20 Juni en 1 Juli 1694.

3) Als roren, 19 September en 7 November 1694.

4) Als voren, 7 Maart 1695.

5) Als voren, 20 Mei 1714, 15 September 1715, 19 Mei 1719.

6) Als voren, 31 Mei 1721.

7) Als voren, 7 Maart 1734 .

8) Als voren, 25 Maart 1736

9) Zijn beroep werd door den Raad van State geapprobeerd op 5 September 1705. 
den dienst te Oostburg te hebben waargenomen vertrok Fauchereau in het najaar van 1710 naar Gorinchem. Zijn opvolger Jean de Romieu, in December 1710 overgekomen van Menin, nam in Juni 1713 een beroep an naar Goes. Nog korter dan de Romieu vertoefde Jean Balguérie de Chautard, die in den zomer van 1713 van Londen overkwam en in October bevestigd werd, te Oostburg, want reeds in December 1714 vertrok hij naar Zierikzee. De vacature werd in 1715 vervuld door den proponent Claude Segond de Chaufepié, na wiens overlijden (op het laatst van 1718 of in het begin van 1719) men wederom een proponent beriep, Jean Daniël Sprenger, die na een verblijf van twee jaar in Juni 1721 in den dienst van Veere's Walenkerk overging en in September daaraanvolgende vervangen werd door den proponent Pierre Asimont, die tot op zijn dood in 1745 - langer dan een van zijn voorgangers of opvolgers - het herdersambt bij de Oostburgsche Walen heeft verruld ${ }^{1}$ ).

Afgezien van de legaten, van tijd tot tijd gelijk wij zagen aan de diaconie ten deel gevallen, viel er in al die jaren (1705-1745) niet veel belangrijks in de gemeente voor. Enkele gebeurtenissen mogen niet onvermeld blijven.

Bij den plundertocht der Fransche troepen in StaatsVlaanderen van $29 \mathrm{Juli} 1708$, die aan de inwoners van Oostburg een schade toebracht van bijna 41820 gulden ${ }^{2}$ ), trof de gemeente het ongeluk van haar avondmaalsgerei beroofd te worden. Het werd eerst na verloop van twee jaar vervangen door een nieuw stel, haar door den Raad van State geschonken ${ }^{3}$ ).

Opmerking verdient verder een kerkeraadsbesluit van 16 December 1722, dat bij voortduring na afloop van de predikatie de artikelen des geloofs moesten worden voorgelezen, en dat het Arondmaal zou gevierd worden in

1) Bulletin, III, p. 324, 325.

2) Brieven van het Vrije aan de Staten-Generaal, van 31 Juli en 5 September 1708.

3) Verbaal Vlaanderen Raad van State voorjaar 1710; Resolutie Raad van State 13 Mei 1710. 
staande houding. Merkwaardig was ook de gedragslïn, die men te Oostburg aannam ten opzichte ran de nieuwe psalmberijming ran Conrard. Immers, ofschoon de kerkeraad in den lastbrief, dien zij Duval medegaf roor de najaarsSynode van 1701, verklaard had de oude berijming van Clément Marot en Théodore de Bèze uithoofde van haar barbaarsche en onverstaanbare woorden en zegswijzen niet te willen behouden '), bleek men daar echter te Oostburg naderhand zoo zeer aan te zijn gehecht, dat men aan de Synode, die in het najaar van 1715 bijeenkwam, den wensch te kennen gaf dat er in de psalmen geen verandering zou worden gebracht maar dat men ze zou blijven zingen volgens de thans gebruikelijke berijming ${ }^{2}$ ). Inderdaad is men dan ook te Oostburg, evenals trouwens te Cadzand on te Groede, zich van de berijming van Marot en de Bèze blïven bedienen ${ }^{3}$ ) nog lang nadat die van Conrard door de Synode goedgekeurd en haar invoering door de StatenGeneraal toegestaan was ${ }^{4}$ ).

Opmerkelijk is roorts de gestrengheid waarmede gedurende dit tijdperk de kerkelijke tucht werd toegepast. Zoo censureerde men in 1741 iemand, omdat hij drie- tot viermaal met de kaart had gespeeld en daarbij, wat echter roor den kerkeraad geen verzachtende omstandigheid was, een vrij groote geldsom bad verloren ${ }^{5}$ ). Van denzelfden puriteinschen geest spreekt een ander besluit, in 1742 genomen, om de weeskinderen in uniform te kleeden en hun het dragen van sieraden te verbieden, opdat langs dien weg alle denkbeelden van hoovaardij bij hen onderdrukt zouden worden ${ }^{6}$ ).

Terwijl Balguérie, de Chaufepié, Sprenger en Asimont

1) Kerkeraadsacta, 24 Augustus 1701.

2) Als voren, 1715.

3) Blijkens een brief van den Waalschen kerkeraad van Groede aan het Vrije van 2 Haart 1753 gebruikte men destijds te Cadzand en Oostburg nog de berijming van Marot en de Bèze.

4) Resolutie Staten-Generaal 18 Januari 1727.

5) Kerkeraadsacto, 29 Juni 1741.

6) Als voren, 10 Januari 1742 
te Oostburg stonden vonden de Walen gelegenheid om de Nederduitsche zustergemeente de gastvrijheid te vergelden, welke deze in vroeger dagen aan de Hugenoten had bewezen. In den nacht van 18 op 19 Augustus 1714 werd namelijk de Hollandsche kerk door den bliksem getroffen en geheel in de asch gelegd, en van dien oogenblik af tot in 1726, toen zij weder zoover opgebouwd was dat de dienst er in kon plaats hebben, hield de Nederduitsche gemeente haar samentomsten in het Fransche bedehuis. Daar bij den brand ook het uurwerk er de klokken teloor waren gegaan, bediende men zich met goedvinden van den magistraat van het stadhuisklokje om de geloovigen tempelwaarts te roepen. De klank was weliswaar niet zwaar genoeg maar, in afwachting dat de gemeente door den Raad van State van een nieuwe klok en uurwerk zou worden voorzien, behielp men er zich mede, totdat in Augustus 1739 het bouwvallige stadhuistorentje met klok en al naar beneden stortte ${ }^{1}$ ). Tot orernaat van ramp liet de berooide staat van de stadsfinantiën niet toe de noodige herstellingen aan te brengen, zoodat men tot spot $\operatorname{van}$ de andersdenkenden met name van de Roomschen voortaan genoodzaakt was de gemeente met tromgeroffel kerkwaarts te roepen. $0 m$ aan dien toestand een einde te maken verzocht het consistorie aan de Waalsche Synode bij de hooge regeering in den Haag op verbetering to willen aandringen ${ }^{2}$ ). Dank zij de bemoeiingen van de Nederduitsche classis van Walcheren, die bij den Raad van State voor de belangen der Nederduitsche gemeente opkwam, en een request, door den magistraat van het stadje bij hem ingediend, trok de Raad zich de zaak aan en gaf den ontranger der kerkelijke goederen van Aardenburg en Oostburg order om een onderzoek in te stellen ${ }^{3}$ ). Intusschen was, nieuwe ramp! de trommelslager ziek geworden en de trommel, die sedert doch "met geen meesterhand" door het zoontje van den predikant werd

1) Resolutie Raad van State 3 Juni 1740.

2) Kerkeraadsacta, 24 Augustus 1739.

3) Resolutie Raad van State 11 Januari 1740. 
gehanteerd, in het begin van Januari 1740 gebroken, waardoor men in het geheel geen middel meer bezat om de gemeente samen te roepen ${ }^{1}$ ). Gelukkig viel het advies van den ontranger gunstig uit en ontring deze, overeenkomstig zijn voorstel ${ }^{2}$ ), in de maand Juni van den Raad van State machtiging on de leverantie van de klok publiek aan te besteden ${ }^{3}$ ), die daarop in October in gebruik werd genomen ${ }^{4}$ ).

$\mathrm{Na}$ het overlijden van Asimont in 1745 opende zich voor de gemeente bet uitzicht op een niet onbelangrijke vermeerdering van haar zielental door de overkomst van eenige réfugiés uit de omstreken van Doornik. Volgens een bericht, op het laatst van Januari 1746 uit Oostburg aan den Raad van State afgezonden door Jean Nicolas Magnet, die bij den overgang van Doornik aan de Franschen in Mei 1745 zijn post als pasteur aldaar had moeten verlaten en in het najaar tot opvolger van Asimont te Oostburg was beroepen - volgens het bericht van Magnet waren een aantal huisgezinnen uit het Doorniksche voornemens zich naar Oostburg te verplaatsen, zoo hun in den beginne slechts eenige hulp en steun werd verleend. Magnet gaf daarom hun Edelmogenden in bedenken of de Armenkas van zijn vorige gemeente, welke bij aan hun secretarie had overgegeven, niet ter beschikking van de Oostburgsche Walendiaconie kon worden gesteld net last om daarvan geen gebruik te maken als tot dienst van de voorzeide Gereformeerde refugiés, en daarvan jaarlijks rekening te doen" aan hunne Gedeputeerden, die telken jare de restingwerken in Staats-Vlaanderen kwamen inspecteeren 5). De Raad had tegen Magnet's roorstel geen bezwaar ${ }^{6}$ ), en van nu af werden de ruim tweeduizend gulden, die van de Doorniksche diaconie afkomstig waren, door den ontranger

1) Kerkeraadiacta, 10 Januari 1740.

2) Brief van den ontoanger Evertse aan den Raad van State van 11 Januari 1740.

3) Resolutie Rand van State 3 Juni 1740.

4) Kerleeraadsacta, 20 October 1740.

5) Resolutie Raad van State 2 Februari 1746.

6) Resolutie als voren. 
van de Waalsche Armen te Oostburg als een afzonderlijk fonds beheerd en ieder jaar geregeld verantwoord ${ }^{1}$ ).

Inderdaad hebben zich kort na de intrede van Magnet (in Januari of Februari 1746) eenige Gereformeerden uit het land van Doornik te Oostburg nedergezet.

Daar aan het fonds geen zware eischen werden gesteld kon men van de inkomsten iets opleggen en bij de rekening, welke in Juni 1749 door de Gedeputeerden uit den Raad van State werd afgehoord, een batig slot aanwïzen van ruim negenhonderdtachtig gulden.- Maar de kans was rolstrekt niet uitgesloten, zoo werd door den kerkeraad aan de Gedeputeerden verzekerd, dat men die som vroeg of laat zou moeten aanspreken, want als de mans of vrouwen $\mathrm{kwamen}$ te sterven zouden er, zeiden zij, wel drie of vier van die Doorniksche huisgezinnen armlastig worden en die zouden zij onmogelijk uit de inkomsten van hun eigen diaconie kunnen onderhouden, aangezien deze èn door den inval der Franschen in Staats-Vlaanderen van April 1747, waarbij het gewest deerlijk geplunderd en gebrandschat was geworden, èn door de nu al een jaar durende pasteursvacature dermate was verarmd dat zij voor de bedeeling van hun eigen armen geld ter leen hadden moeten opnemen. Met het oog daarop vroegen zij verlof om het saldo van het Doorniksche diaconiefonds te mogen „blijven manieeren on op vast hypotheek ten intereste uitgeven", onder bepaling, dat de rente uitsluitend zou worden besteed "tot onderhoud van de arme Doorniksche familiën zich tot Oostburg onthoudende" op den voet als indertijd door den Raad van State was bepaald ${ }^{2}$ ).

Met de inwilliging van dat verzoek - het gerraagde werd den 26 November 1749 werkelijk toegestaan ${ }^{3}$ ) bandelde de Raad feitelijk in strijd met een vroeger door

1) Brief van den kerkeraad aan den Raad van State van 17 Februari 1754.

2) Request door den kerkeraad overgegeven can de Gedeputeerdon van den Raad van State, begin Juni 1750 (zie hun verbaal).

3) Blijkens kantbeschikking op evengenoemd request (Ingekomen brieven Raad van State, 15 April 1750). 
hem genomen besluit, van 24 Juni 1749, waarbij het saldo weder ter beschikking was gesteld van de Waalsche kerk te Doornik, die na den vrede van Aken in 1748 opnieuw was opgericht en haar voormalige diaconiekas weder ten behoeve van haar eigen armen had teruggevraagd ${ }^{1}$ ). Bij herhaling $\mathrm{kwam}$ nu in het verrolg de kerk van Doornik op de zaak terug, doch of de Raad van State al telkens en telkens weer gunstig op baar verzoekschriften beschikte on aan den Oostburgschen kerkeraad de teruggave gelastte ${ }^{2}$ ), of die ran Doornik al beloofden, dat zij de uit hun omtrek afkomstige armen te Oostburg zouden onderbouden ${ }^{3}$ ), en de Oostburgers keer op keer tot restitutie van het fonds aanmaanden ${ }^{4}$ ), zij $\mathrm{kwamen}$ geen stap verder. De kerkeraad van Oostburg zocht, zooals de pasteur en kerkeraad ran Doornik het in hun brieven aan den Raad van State noemen, maar gedurig "onnoozele uitvluchten" en bleef "met hun diaconiegeld leven" alsof het zijn eigendom was, en toen bij eindelïk den hypotheekbrief naar Doornik overzond, kon men er daar niets mede aanrangen daar deze een bepaling behelsde, waarbij aan hem, door wien de hypotheek was opgenomen, verboden werd het kapitaal of de rente aan de kerk van Doornik uit te betalen ${ }^{3}$ ).

Ten slotte, nadat met schrijven en wrïven ruim zeven jaar waren heengegaan, maakte de Raad van State aan het gehaspel een einde: den 20 Augustus 1756 nam hij een besluit, waarbij de Oostburgers werden geordonneerd "om aan die ran den kerkeraad te Doornik vrij en onverlet te laten om met den voorschreven hypotheekbrief te handelen, de roorgeschreven interessen te ontrangen en bet kapitaal op te eischen, zooals zij ten nutte van hun armen zouden oordeelen te behooren, en over zulks in te trekken

1) Brief van den Doornileschen kerkeraad aan den Raad van State van 27 Januari 1751.

2) Resolutiēn Raad van State 15 April 1750 en 3 Februari 1751.

3) Brief oan den Doorniksehen kerkeraad aan den Raad van State van 3 Maart 1750.

4) Brief van als voren aan als voren van 20 Januari 1754.

5) Brief van als voren aan ais voren van 11 Augustus 1756. 
alle zoodanige ordres als zij daartegen zouden mogen hebben gegeren", terwijl anderzijds de kerkeraad van Doornik werd gelast aan den ontranger van de Armen te Oostburg te rembourseeren het bedrag, dat deze bij zijn laatste rekening en verantwoording was "te boven gekonıen", alsmede om "de armen van Doornik te Oostburg zijnde te onderhouden of bij haar te doen overkomen".

Onder al die bedrijven was Magnet in Juni 1740 overleden. Zijn opvolgers in de eerste jaren waren de proponenten Jean Mazel, die in Juli 1749 in dienst trad doch reeds in September naar Vlissingen vertrok, Jean Isaac Sporon, die na te Oostburg van Mei 1751 af werkzaam te zijn geweest omstreeks half October ${ }^{1}$ ) een beroep aannam naar Paramaribo, Philippe Pastre Gonnet in Januari 1753 berestigd en in Mei 1755 overleden, en Theodore Vermeer, die zijn dienstwerk albier aanving in September 1755 en het in Juni 1761 verwisselde met het predikambt bij de gemeente van Dalhem ${ }^{2}$ ).

Terwijl Vermeer te Oostburg stond besloot de kerkeraad behalve de gewone Zondagspredikatiën ook een aronddienst te bouden in de week, en daarvoor bij den Raad van State de vereischte benoodigdheden aan te vragen. Het verzoek rond bij hun Edel Mogenden een goede ontrangst. Den 23 December 1757 verleenden zij machtiging om voor rekening van bet land aan to koopen een koperen lichtkroon van zes of zeven armen, een dubbelen koperen blaker voor den preekstoel en vierentwintig enkele blakers van geslagen koper om in de kerk te plaatsen, terwïl zij bovendien een jaarlïksche bijdrage toezegden voor bet koopen van kaarsen ${ }^{3}$ ). Dientengevolge kon in November 1758 met het houden van avondpreeken een begin worden gemaakt ${ }^{4}$ ).

Een andere verbetering, meer in het bïzonder ten be-

1) Blijkens de kerkeraadsacta werd hij van de gemeente ran Oostburg los gemaakt op 18 October 1751 .

2) Bulletin, III, p. 325.

3) Resolutic Raad van State 22 December 1757.

4) Kerkeraadsacta, 15 November 1758. 
hoeve van den predikant, poogde men tot stand te brengen onder het herderschap van Jean Jacques Bourcard, die ter vervanging van Vermeer op het laatst van 1761 uit Bazel herwaarts was geroepen 1). Minder gelukkig in dat opzicht dan hun Nederduitsche ambtsbroeders hadden de Walenpredikanten van Oostburg nimmer het genot gehad van een vrije pastorie. Dit leverde, afgezien van de kosten, des te grooter ongerief voor hen op omdat de woningennood hen niet zelden dwong zich met een gehuurde kamer terreden te stellen tot tijd en wijle een huis te koop of te huur $\mathrm{kwam}{ }^{2}$ ); en als er huizen beschikbaar kwamen, bleken die gewoonlijk zoo klein en ,miserabel", dat zij voor een predikant schier onbruikbaar waren ${ }^{3}$ ). Misschien lag het evenzeer daaraan als aan de niet hooge bezoldiging ${ }^{4}$ ), dat met de verrulling van vacatures, onder anderen na het afsterven van Magnet, zoo reel tijd gemoeid was geweest ${ }^{5}$ ). Wel had het "collegium qualificatum" meer dan eens bij de regeering in den Haag aangehouden dat hierin van 's lands wege zou worden voorzien, hetzij door het koopen van een geschikt perceel hetzij door het bouwen van een nieuw huis, maar altoos te vergeefs. In 1753 had de Raad van State zich weliswaar bereid verklaard om ten behoeve van den pasteur "een bekwaan huis tot een redelijken prijs voor een goed getal van jaren in te huren", en den ontvanger van de kerkegoederen van Aardenburg en Oostburg opgedragen om na te gaan of dit uitroerbaar was $\%$, doch na diens bericht dat or in

1) Bulletin, III, p. 325.

2) Brief van den ontvanger Sappius aan den Raad van State van 18 A ugustus 1751.

3) Resolutie Raad van State 23 Augustus 1751.

4) De ontvanger Sappius berekende in zijn aangehaalden brief van 18 Augustus 1751 de zuivere jaarlijksche inkomsten van den pasteur op $f 600$.

5) Zoo wordt het ten minste door het colleqium qualificatum voorgesteld in een request aan den Raad van State, zie diens resolutie ran 23 Augustus 1751.

6) Resolutic Raad van State 19 October 1753. Een vroeger request van gelijke strekking was door den Raad bij resolutie van 23 Augustus 1751 afgewezen. 
gansch Oostburg geen enkel huis ja niet eens een kamer to verkrijgen was, zoodat de pasteur voorloopig zelfs de gastrrijheid van een particulier had moeten inroepen 1 , was de zaak blïren rusten. Zoo sukkelde men voort tot zich in 1764 een gelegenheid opdeed, die gunstiger kans bood. In den loop van dat jaar had namelijk de Raad van State aan de gemeente op haar verzoek toegestaan, dat er op 's lands kosten tegen den achtergevel van de kerk een consistorie zou worden gebouwd 2), die men tot dusver noode had gemist. Toen in 1766 met dit werk zou worden begonnen, namen de kerkmeesters met Bourcard de gelegenbeid te baat om een verzoek in te dienen, dat de consistorie in plaats van tegen den achtergevel tegen den zijmuur mocht opgetrokken worden en tevens door het aanbouwen van eenige kamertjes ingericht tot pastorie. De bezwaren, die in den Haag vermoedelijk tegen het voorstel zouden rijzen, werden bij voorraad op zijde geschoven doordien de magistraat zich bereid verklaarde kosteloos het benondigde bouwterrein te verschaffen, en daarenboven door de toezegging, dat de meerdere uitgaven, die met het plan gepaard gingen, bestreden zouden worden uit vrijwillige liefdegiften van de gemeente en andere belangstellenden ${ }^{3}$ ), zoodat bij slot van rekening uitsluitend het onderboud ten laste van den den staat zou komen. Uitteraard zal dit laatste, dat natuurlijk in de eerste jaren luttel of geen uitgaven zou vorderen, bij den Raad van State niet zoo beel zwaar bebben gewogen. Er waren echter nog andere omstandigheden die gewicht in de schaal legden. De kerkmeesters toch hadden naderhand de vrees uitgesproken, dat de liefdegaren van de grootendeels uit arme lieden bestaande Walengemeonte op verre na niet toereikende zouden blïken, zoodat, als men het plan wilde doorzetten, naar alle gedachten de Staat toch met een aanzienlijke gift zou

1) Brief van Sappius aan den Raad van State van 9 November 1753.

2) Resolutie Raad van State 1 Augustus 1764.

3) Brief van Sappius aan den Raad van State van 5 April 1766. 
moeten bijspringen 1). Daarenboven had Bourcard verklaard niet in staat te zijn om, gelijk de Raad van State voorsloeg, van de honderd gulden, welke hï jaarlïks boven zijn tractement voor huishuur genoot, ook maar iets te laten vallen als vergoeding voor vrije woning, daar het hem, gelïk bij zeide en door de kerkmeesters bevestigd werd, nauwelijks mogelijk was met zijn salaris rond to komen ${ }^{2}$ ). Redenen te over naar het oordeel van den Raad om niet verder op de zaak in te gaan en het request van de hand te wijzen ${ }^{3}$ ). Eerst in 1782 tijdens den dienst van den laatsten pasteur op écn na, die bij de Oostburgsche gemeente heeft gestaan, kwamen de Walen eindelijk in het bezit van een eigen pastorie. Zij hadden haar te danken aan een testamentaire beschikking van wïlen Marie Jeanne le Saffre, weduwe van Erançois Louis Caignet, die, behalve honderd pond in los geld aan de diaconie, tevens het door haar bewoonde huis roor dat doel legateerde 4 ).

$\mathrm{Na}$ Bourcard, die in November 1773 overleed, heeft de gemeente slechts drie predikanten meer gehad: Louis Robert, van November 1774 tot op zijn dood in September 1776 ; Adrien van Groenevelt, als proponent in Augustus 1777 berestigd en in November 1785 naar Paramaribo vertrokken; Joseph Picard, die in Juli 1788 van Bleigny overkwam 5).

In hun tijd begon het ledental hoe langer hoe meer achteruit te gaan. In December 1763 meldde zich niemand

1) Blijkens hun memorie van 2 Juni 1766 door Sappius bij zijn missive van 4 Juli 1766 an den Raad van State overgelegd. In die memorie uilten zij inderdaad den wensch, dat de Raad de eventueel na de collecte nog te kort komende som nliefdadiglijk" geliefde te nsuppleeren".

2) Memorie als voren.

3) Resolutie Raad van State 24 Juli 1766.

4) Kerkeraadsaeta, 6 Januari 1782.

5) Bulletin, UI, p. 325. De vacature was hoofdzakelijk wegens het geringe tractement zoo lang onvervuld gebleven. Eerst nadat de Raad van State op aandrang van het "collegium qualificatum" in 1787 het salaris van 500 op 600 gulden had gebracht (resolutie 6 Maart 1787), slaagde men er in voor Groenevelt een oprolger te vinden. 
aan voor de aanneming, iets wat zoolang de gemeente bestond nog nimmer was voorgekomen en den kerkeraad, gelijk in zijn acta-boek staat aangeteekend, met de vrees vervulde dat "de eertijds zoo talrijke en bloeiende gemeente" volslagen te niet zoude gaan 1). Echter werd die vrees nog langer dan een menschenleeftijd door de uitkomst gelogenstraft. Nog in 1770 werden er zoowel binnen als buiten de stad tachtig lidmaten aangetroffen 2), zeker geen onbeduidend getal als men in aanmerking neemt, dat er bij de oprichting der kerk in 1686 in het geheel slechts honderdveertig waren. Zelfs de inlijving van StaatsVlaanderen bij Frankrijk in 1795, hoe nadeelig ook, bleek niet in staat haar taaie levenskracht uit te blusschen. Wel rond Picard, die voortaan zijn landstractement moest missen, zich genoodzaakt in Semptember 1795 zijn ontslag te nemen 3), wel werd de gemeente evenals de andere Waalsche kerken in Staats-Vlaanderen sedert 1802 door de Waalsche Synode niet langer als lid van haar vergadering erkend 4), doch in weerwil van dit alles bleef zij in wezen en écus in de maand onder voorgang ran Ds. Maurel van Sluis haar godsdienstoefeningen houden 5).

Alleen moest zij, aan een familie gelijk die in verval komt, haar roet van leven gedurig inkrimpen en op haar huishouding bezuinigen zooveel zij maar kon. In plaats van het oude nu veel te groot geworden bedehuis, dat

1) Kerkeraadsacta, 4 December 1763: Et notez qu'il n'y s'est trouvé aucun catéchumène pour la communion de l'année prochaine, ce qui n'est encore jamais arrivé depuis la fondation de notre église l'année 1686, et qui nous fait craindre hélas! la décadence totale d'un nombreux et très-florissant troupeau de jadis".

2) Brief van het Vrije aan den Raad van State van 13 October 1770.

3) Kerkeraadsacta, 29 September 1795. Op 30 Juni 1795 had de kerkeraad, daar de gemeente zelve onmachtig was het tractement bijeen te brengen, aan Picard in overweging gegeven zich tot de Nationale Conventie te Parijs te wenden, en besloten inmiddels aan de directie van den Generalen Prins Willempolder een voorschot te vragen om Picard voorloopig te helpen, waaraan later voldaan werd.

4) Krachtens besluit der Synode van Leiden ran Juli 1802.

5) Mededeeling van Dr. H. A. Callenfels (geneesheer te Oostburg van 1816-1860) in Van der Aa, Aardrijkskumdig Woordenboek, VIII, blz. 482. 
in Januari 1804 voor drieduizend gulden aan de Roomschen werd overgedaan 1), kocht men voor duizend gulden een paar huizen aan de Oost- of Brouwerijstraat om tot kerk in te richten 2). Het nieuwe kerkje, dat behalve de overheids- en kerkeraadsbanken omtrent rïftig zitplaatsen bevatte en van een net orgeltje was roorzien, werd den 26 Juli 1805 met een toepasselijk woord van Ds. Maurel in gebruik genomen 3).

Toen Maurel in November 1806 was overleden trachtte men weer een eigen leeraar te verkrijgen, die orereenkomstig een tusschen deze beide kerken aangegane verbintenis de Walen van Aardenburg en Oostburg in combinatie zou bedienen. Ongelukkig waren er destijds geen Waalsche proponenten beschikbaar noch predikanten te vinden, die genegen waren een beroep naar Oostburg aan te nemen, zoodat men ran tijd tot tijd de hulp moest inroepen van de Fransche predikanten van Middelburg en Vlissingen ${ }^{4}$ ). De onkosten, die dit medebracht, vielen echter de gemeente op den duur te zwaar om op dezen voet voort te gaan ${ }^{5}$ ). $\mathrm{Na}$ een vruchtelooze poging om den Nederduitschen predikant van Bierrliet, Ds. Basselaar, tot zulk een regeling over te halen, vond men in 1812 diens ambtgenoot van St. Anna ter Muiden, Ds. J. A. Janssen, bereid om tegen een gratificatie van honderdvijftig gulden 's jaars catechizatie te komen houden en éens in de maand voor de gemeente op te treden ${ }^{6}$ ).

$\mathrm{Na}$ den val der Napoleontische beerschappij schijnen de Oostburgsche Walen, thans nog rijfendertig tot veertig

1) Van der $A a$, a. w., VIII, blz. 486, waar tevens medegedeeld wordt dat het gebouw, sedert als kerk voor de Roomschen dienend, aan vankelijk in denzelfden toestand bleef, totdat het in 1822 ruim de helft in lengte vergroot en van een geheel nieu wen voorgevel en een kloktorentje werd voorzien. Op het laatst van de 19 de eeuw is het door de burgerlijke gemeente aangekocht en voor graanbeurs ingericht.

2) Van der $A a$, a. w., VIII, blz. 486, en Kerkeraadsacta, 1805.

3) Van der $A a$, t. a. p.

4) Als voren, en Kerkeraadsacta 1806.

5) Van der $A a$, a. w., VIII, blz. 482.

6) Kerkeraadsacta, 1812. 
personen sterk, een tijdlang de hoop te hebben geroed dat het hun gelukken zou van rijkswege een bezoldiging te verkrijgen roor een eigen pasteur. Een verzoekschrift van die strekking werd in September 1814 op diens doorreis door Oostburg aan den Souvereinen Vorst overhandigd; men riep de voorspraak in van den secretaris der Waalsche Synode, Ds. de Chaufepié te 's-Grarenhage, wendde zich gedurende de jaren 1815, 1816 on 1817 tot den Minister van Eeredienst en de Waalsche Commissie - niets mocht baten. Den 29 Augustus 1817 werd de Waalsche predikantsplaats te Oostburg opgeheren en de gemeente bij de Nederduitsche kerk ingelijfd.

Reeds vóbr men te Oostburg van dit besluit der regeering tiijding had ontvangen ') hadden de veertien leden, waaruit de gemeente op dat oogenblik nog bestond, den kerkeraad gemachtigd om met de Nederduitsche broederen over de vereeniging in overleg te treden. Den 12 September word dienaangaande een overeenkomst getroffen, den 14 October daaraanvolgende sloten de kerkeraadsleden in plechtige zitting hun laatste notulenboek met het plaatsen hunner handteekeningen ${ }^{2}$ ) en op den 21 December van hetzelfde jaar 1817 hield Ds. Janssen met een toespraak over de woorden I Corinthen XIII, 13a: „En nu blijft geloof, hoop en liefde" zijn afscheidspredikatie, tegelijk de lijkrede orer de ten onder gegane gemeente ${ }^{3}$ ).

1) Het werd op 20 September 1817 ter kennis van den Waalschen kerkeraad gebracht.

2) Kerkeraadsacta, 14 October 1817.

3) Van der Aa, a. w., VIII, blz. 482. - Op den 1sten Mei 1913 werd door den Nederduitschen kerkeraad in den voorgevel der Oostburgsche graanbeurs een eenvoudige gedenksteen geplaatst met het volgende opschrift: -Ter gedachtenis aan de gevluchte Hugenoten, die in dit gebouw van 1689-1303 hunne godsdienstoefeningen bebben gehouden. A la mémoire des réfugiés huguenots qui dans ce bảtiment-mème célébraient leur culte. 1689-1803".

$\mathbf{x}$. 


\section{BIJLAGE.}

Liste des réfugiés dans la ville d'Oosburgh et aux environqui desirent se retirer à l'Eglise françoise qui commencedes'yestablir 1).

Samuel Georges autrefois ministre à Amiens en Picardie, sa femme, sa servante - Daniël Bosbergue ancien, chirurgien La refve Mario Charlet veure d'un laboureur et cinq enfans communiants *) - Jerosme Watté chartier pour le püblic, Pierre Watté, Jean Watté, Jacob Watté, Judith Si sa fomme, Judith Rouze, ne peuvent signer, le père a paraphé pour eux*) Jean le Cant travailleur en lin, Pierre, Susanne, Susanne (his), Cathérine, Charles, Catherine de Lo, la signature du père* ${ }^{*}$ Daniel Oigne batteur en grange. - Michel Gueffroy batteur en grange - Habraham Lhommeaux manouvrier - Balthasar Pottie manouvrier - Rachel Broche couturière - Susanne Porée lavandière - Abraham de Lis paisan - Sara le Noir - Jacques Stripaert manourrier - Jacques Ojeux marchand de lin - Jean Saurage ancien, laboureur et Susanne Bonnel sa femme arec cincq enfans - Jean Saurage laboureur, Susanne, Pierre Sauvage, Abraham, Isaac - Pierre Jolly et Anne de Viller ma femme et sept enfant, Louy Lucaer laboureur, Anne Lucaer laboureur, Madelinne Lucaer, Danielle Lucaer, Mary Joly, Pier Joly, Rachelle Jolly - Charle Verlin linier - Jene Foulon - Jean Joly marchand de lin, Anne Herondart, Louis, Jean Jolly, Anne

1) Deze lijst zoowel als de hierachter volgende werden door den Raad van State bij missive van 25 A pril 1686 toegezonden aan de Staten-Generaal. „De Heeren onze gedeputeerden jongst geweest zijnde in Vlaanderen (zoo schrijit de Raad, hebben tot voldoeninge van U Hoog Mogenden resolutie, beide in datis den 15 Februari laatst leden genomen op de requeste van baljuw, burgemeester en schepenen der stede en schependomme van Aardenburg en van den magistraat der stad Oostburg, haar Ed. geinfurmeerd op den toestand en gelegenheid der respective Fransche gemeentens der voornoemde steren, en aan ons overgeleverd twee distincte lijsten, behelzende de quantiteit en qualiteit der vluchtelingen zich in de voors. plaatsen geretireerd hebbende, zulks als U Hoog Mogenden uit dezelve lijsten hiernovens gaande gelieven te zien".

De namen zijn voor een deel door de opgesomde personen zelf op de lijst geplaatst, terwijl de met een angeduiden met een kruis of ander merk hebben geteekend. 
Herondart, Marie Madeline - Pierre Guemart laboureur et 4 enfans, a fait sa marqüe *) - Jacques Buseine linier a déclaré ne pouvoir signer, Ester Buseigne - Pierre du Pont laboureur fermier - Jean du Pont - Abraham du Bois de Schondic manouvrier - Jean Messian manouvrier - Pieter Sauvage fermier - Nicolas Tassé berger - David Amiot fermier et sa femme Judieth Picaret - Marie de Lengaygne marchande - Mari de Lavalle fileuse - Moyse Mortier valet de paysan - François Paulus Koevoet charton - Geert de, Waal sergent de ville, Cécile sa femme, Marguérite, Françoise, Liérine, Sara fileusoMarye Kornyle fleuse - Elisabeth Carens - Jean Lavoir manouvrier a déclaré ne pouvoir signer, Elisabeth Rikart sa femme - Susanne Landa - Daniël Pieter fermier - Elizabeth Sauvage - Jean du Pré tonnelier - Daniël Lange fermier, sa femme, 3 enfans - Jean du Mon fermier, Anne de Revier ma femme, Jean du Mon mon fils, Ane du Mon ma fille - Pierre des Camps berger - Barbe de Saint - Arnoult - Somay et S. (sic.) - Anna - Marie de Vauhen a parafe*) - Pierre de Binwre (?) manourrier - Pierre Patonart item - Abraham de Saint item - Jean Galet item - Mario Barisseau boutiquillière - Nicolas Sauvage marchand de lin - Jacques Lorrain manouvrier - Abraham de Noult (?) item - Jean Bouquet item - Pierre Bouquet item - Pierre Costeu linier, Marie le Comte sa femme, un enfant - Eustache de l'Angle laboureur - Guilain Boucaut linier - Jaques Savate boulanger - Antoine Magnier manourrier - Abraham Peudepiece tailleur - Pierre Lheureux manourrier - Jean Boucherie item, Mar (sicl), Marie Rubriau sa femme - Madelaine Verlaigne fleuse - François Maran manourrier - Estienne Cousin manourrier - Jean Croizet fermier, sa femme, deur valets fermier - Jean Bouchen fermier et Marie Moriancourt et un enfant - Jacque Tellier mousnier et Jene Prurost sa femme et quatre enfan Pierre, Jaques, Jeanne, Susanne - Bernard Leste, sa femme et six enfans - Gaspard Laigne fermier et sa femme et sa famille a declaré ne pouvoir signer *) - Jacques le Sage paysan et sa femme, deux enfants Jean et Marie Jacob del Haje fermier a déclaré ne pouvoir escrire - Noé de Laval lecteur, Marie Carlié sa femme, Anne de Laval sa fille, Noé de Laval son fils - Pierre Dauchy manourrier sa femme et ses enfans a declare ne pouvoir escrire ${ }^{*}$ ) - Joseph Grimourie (?) manourrier - Isaac Planque, sa femme et deux enfants declare 
ne pouvoir signer - Nicolaes Grouseit fermier du bailly et Francçoisse Grouseit - François Mullié manourrier - Pierre le Febres manourrier et sa femme - Philippe Rebreau Judith Carron fleuse, Madelaine Mulier sa fille - Jehan van Hos paysant, aa femme et trois enfans Magdelaine, Jean et Jeanne - Jean Plancq manourrier, Elisabeth ma femme et deux enfans - Marie Btaque 5 enfans.

Il $\mathrm{y}$ en a quelqu'autres qui cherchent incessamment à louer des maisons et terres.

Est à noter que ce sont tous Picards, gens aguerris et laborieux, capables de garder des frontières.

$$
\begin{aligned}
& \text { Roolle des francois qui sesont } \\
& \text { retirés dans la rilled Ardembourg } \\
& \text { àcausedelapersecutionde France. }
\end{aligned}
$$

Francois de la Resseguerie ministre, natif de Montauban Marc de Lajus marchand, Esther de Lajus sa fille, autre Esther de Lajus ea niepce - Jean Marte laboureur, Sara Marte, Magdeleine Marte, Marie Marte, Jeane Marte, Esther Marte ses 5 enfants - Judith Jesnel vefre, Abraham Magnel son fils, Isaac Magnel son autre fils - Guilliaume Hurel marchand, Marie Laganne 1) sa femme, Guilhaume Hurel leur fils - Jaques Lagarne laboureur, Pierre le Taille son cousin - Abraham Valentin tisserand, Marie de Sombre 2) sa femme, Abraham Valentin leur fils, Sara Valentin leur fille - Jaques Blanchart marchand, Sara Hars sa femme - Pierre Prerost tourneur, Esther Businne sa femme - Simon de Seine laboureur, Magdeleine Ouatrelou 3) sa femme, Magdeleine de Seine, Simon de Seine, Marie de Seine, Cathérine de Seine, Susanne de Seine, Isaac de Seine leurs 6 enfans - Pierre de Seine laboureur, Marie Desdour sa femme, Marie de Seine, Pierre de Seine leurs 2 enfans Jean de Seine son nepreu - Abraham Brevet marchand, Judith Morillon sa femme, Abraham Brevet leur fils - Daniël de la Haine charpentier, Judith Catel sa femme, Daniël de la Haine lour fils - Susanne Goude refre, Jean

1) In een latere lijst van 9 Juli 1686 koint deze voor als Marie Longaigne.

2) En. 3) In de lijst van 9 Juli 1686: Destombes en Fattelot. 
Hessien 1) son fils - Anne du Four vefve de Marc de Fief, Marc le Fief, Anne le Fief, Jaques le Fief, Marie le Fief ses 4 enfans, Benjamin du Four son cousin - Isaac Celain maître taillheur, Susanne d'Esthienville sa femme, Isaac Celain 2), Jean Celain, Susanne Celain, Esther Celain ses 4 enfans, Claude Vidor, Pierre Vidor, Isaac de l'Ecluse 3 orphelins chez ledit Pierre Celain charpentier, Susanne Celain sa femme, Marie Celain leur fille - François Blanchart taillheur, Jeane Blanchart sa soeur, Susanne Blanchart - Isaac Mension laboureur, Pierre Mension aussi laboureur, Jeanne Mension, Marie Mension, Esther Mension - Isaac le Coq laboureur, Marie le Cō̄ sa soeur - Jacob de Baillieu laboureur, Magdeleine Delbeq sa femme, Jacob de Baillieu, Magdeleine de Baillieu, Susanne de Baillieu, Jeane de Baillieu 4 de leurs enfans - Pierre Goubert laboureur, Sara de Seine sa femme, Pierre Goubert leur enfant Jaques Goubert laboureur, Susanne du Mon sa femme - Salomon Goubert laboureur, Jeane Barbery sa femme, Salomon Goubert leur fils - Jaques Delbeq laboureur, Marie du Rier sa femme, Jaques Delbeq, Nicolas Louiq, Catherine Louiq leurs 3 enfans Susanne Sy 3) refve de Jaques du Mon, Marie du Mon, Elizabeth du Mon, Isaac du Mon, Jeane dn Mon ses 4 enfans Jeane Suartfager vefve de Jean Dutry, Jacob Dutry, Philippe Dutry, Isaac Dutry, Jean Dutry, Abraham Dutry ses 5 enfans Jaques Reux laboureur, Marie le Roy sa femme, Isaac Reux leur enfant - Pierre Toutlemonde tisserand, Judith Noé sa femme, Jean Toutlemonde leur enfant - Marc Huguelo laboureur, Jeane Lory sa femme - Pierre Houveine marchand, Susanne de la Bale sa femme, Pierre Houreine, Jean Houreine, Abraham Houveine, Susanne Houreine, Magdeleine Houveine leurs 5 enfans Anne de Seine - Marie de Seine - Magdelaine Goubert Marie Goubert - Esther le Neu - Abraham Noé laboureur Isaac Noé - Jacob Noé - Marie Noé - Abrabam l'Alemand matelot - Jaques Galet laboureur - Darid Lanoy laboureur Pierre Magnel laboureur - Elizabeth Magnel sa soeur - Jean Coquelar - Daniël de Rube - Pierre du Four - Magdeleine Goudin - Daniël de Benin - Marie Senessart - André Six laboureur - Jacob Six laboureur - André Netus laboureur Anne Naulthier - Jean Naulthier son frère.

1) In de lijst van 9 Juli 1686 : Messien.

2) En. 3) In de lijst ran 9 Juli 1686: Seaulin, Six. 
Le nombre de communiants est 89 , de jeunes hommes, filles et enfans 67 , fait 156 personnes.

Nous sousignés conducteurs de l'Esglise Walonne réformée dans la ville d'Ardembourg certifions que tous les personnes et familljes susnommées ont leur demeurance sous nostre conduite.

Faict à Ardembourg ce 31e de mars 1686.

Pirrre do Bots pasteur, Jask Suttreman ancien. 